\title{
KEMAMPUAN BERPIKIR SISWA DALAM PEMBELAJARAN MATEMATIKA DENGAN PENDEKATAN SAINTIFIK
}

\author{
Anisa' Safitri ${ }^{1}$ \\ ${ }^{1}$ Program Studi Pendidikan Matematika Universitas Negeri Semarang \\ Email: 1 anisasafitri171@gmail.com
}

\begin{abstract}
ABSTRAK
Kemampuan berpikir adalah salah satu faktor penting bagi siswa dalam pembelajaran matematika. Hal ini dikarenakan kemampuan berpikir memiliki peranan yang sangat strategis dalam mengembangkan potensi intelektual anak. Kemampuan berpikir dapat ditingkatkan dengan adanya pembelajaran yang bermakna. Pembelajaran di Indonesia saat ini menggunakan kurikulum 2013 yaitu dengan pendekatan saintifik. Pendekatan saintifik dijabarkan dalam tahapan kegiatan mengamati, menanya, mengumpulkan informasi, mengasosiasi, dan mengkomunikasikan. Pembelajaran matematika dengan pendekatan saintifik dapat meningkatkan prestasi belajar siswa dan meningkatkan kemampuan berpikir matematika siswa. Namun, masalah yang dihadapi saat ini adalah bagaimana cara untuk meningkatkan kemampuan berpikir siswa dalam pembelajaran matematika. Pada pendekatan saintifik, siswa dapat dilatih untuk meningkatkan kemampuan berpikir dengan cara guru memberi pertanyaanpertanyaan menarik dan menantang yang melatih siswa untuk berpikir secara aktif dan kreatif. Penulisan artikel ini bertujuan untuk memaparkan bagaimana cara meningkatkan kemampuan berpikir siswa dalam pembelajaran matematika melalui pendekatan saintifik. Metode penulisan yang digunakan dalam artikel ini adalah studi pustaka. Hasil pembahasan menunjukkan bahwa pendekatan saintifik dapat meningkatkan kemampuan berpikir siswa dalam pembelajaran matematika.
\end{abstract}

Kata kunci: Kemampuan Berpikir, Pembelajaran Matematika, Pendekatan Saintifik

\begin{abstract}
The ability to think is one of the important factors for students in learning mathematics. This is because the ability to think has a very strategic role in developing children's intellectual potential. Thinking ability can be improved by means of meaningful learning. Learning in Indonesia currently uses the 2013 curriculum, namely the scientific approach. The scientific approach is described in the stages of observing, questioning, gathering information, associating and communicating. Learning mathematics with a scientific approach can improve student achievement and improve students' mathematical thinking skills. However, the problem currently faced is how to improve students' thinking skills in learning mathematics. In the scientific approach, students can be trained to improve their thinking skills by the teacher giving interesting and challenging questions that train students to think actively and creatively. The writing of this article aims to describe how to improve students' thinking skills in learning mathematics through a scientific approach. The writing method used in this article is literature study. The results of the discussion show that the scientific approach can improve students' thinking skills in learning mathematics.
\end{abstract}

Keywords: Thinking Skills, Mathematics Learning, Scientific Approach 


\section{PENDAHULUAN}

Pendidikan merupakan salah satu upaya untuk mengembangkan dan meningkatkan sumber daya manusia yang berkualitas, seperti halnya dikemukakan oleh Naisbitt "Education and training must be a major priority; they are the keys to maintaining competitiveness" (Soviawati, 2011). Salah satu upaya yang dapat dilakukan untuk meningkatkan sumber daya manusia adalah meningkatkan kualitas pendidikan yang berfokus pada pengembangan kemampuan berpikir siswa. Salah satu alat untuk mengembangkan cara berpikir adalah melalui matematika (Sulistiani dan Masrukan, 2016).

Matematika merupakan mata pelajaran yang sangat penting. Amir (2015) berpendapat bahwa matematika sebagai ratu ilmu pengetahuan. Artinya matematika merupakan akar dari berbagai ilmu pengetahuan dan menjadi cikal bakal bagi ilmu pengetahuan lainnya. Sehingga dapat dikatakan bahwa semua ilmu pengetahuan bersumber dari ilmu matematika.

Matematika merupakan suatu mata pelajaran yang memiliki peranan cukup penting dalam kehidupan sehari-hari terutama dalam membantu siswa mengkaji sesuatu secara logis, kreatif, dan sistematis (Utari et al., 2013). Oleh karena itu, pembelajaran matematika harus mengutamakan untuk berpikir sistematis, kritis, dan kemampuan pemecahan masalah. Menurut Lambertus (2009) matematika mempelajari tentang pola, struktur, dan keteraturan yang terorganisasi dari unsur-unsur yang tidak terdefinisi ke unsur-unsur yang terdefinisi, hingga ke aksioma atau postulat dan dalil-dalil atau teorema. Komponen matematika tersebut dapat membentuk suatu sistem yang saling berhubungan dan terorganisir.

Kemampuan berpikir dalam matematika sangat penting untuk dikembangkan. Berdasarkan penelitian, kurangnya kemajuan dalam meningkatkan kemampuan matematika siswa di Amerika Serikat menyebabkan Amerika Serikat memiliki implikasi serius bagi daya saing di pasar global. Kemampuan berpikir siswa yang meningkat juga akan berpengaruh terhadap peningkatan prestasi akademik siswa tersebut. Menurut Conklin (2012), ciri utama keterampilan berpikir tingkat tinggi adalah kritis dan kreatif. Pada kurikulum 2013, siswa dituntut untuk dapat lebih kritis dan kreatif. Oleh karena itu, sangat penting untuk melatih kemampuan berpikir siswa.

Peran penting kemampuan berpikir pada matematika terletak dalam proses pembelajarannya. Siswa akan terbiasa berpikir kritis dan kreatif baik dalam pengambilan keputusan dan pemecahan masalah yang berkaitan dengan menganalisis, mengevaluasi dan mencipta. Oleh karena itu dalam proses pembelajaran matematika, siswa harus terbiasa untuk aktif dan guru harus mendorong agar siswa memiliki rasa ingin tahu yang tinggi serta dapat mengembangkan kreativitas dan pemahamannya.

Namun dalam mengembangkan kemampuan berpikir, guru belum memberi kesempatan siswa untuk mengembangkan kreativitasnya. Menurut Widiani et al. (tanpa tahun), dalam proses pembelajaran, guru lebih banyak menyampaikan materi dengan metode ceramah, memberikan rumus singkat, dan mencari satu jawaban yang benar untuk soal-soal yang diberikan. Guru masih jarang memberikan latihan-latihan untuk meningkatkan kemampuan berpikir kreatif dalam matematika. Sehingga hal tersebut menyebabkan siswa kurang memiliki kemampuan menyelesaikan masalah dengan alternatif lainnya.

Sehingga dari hal tersebut, diperlukan adanya suatu perubahan dalam proses pembelajaran. Guru diminta untuk dapat membuat perubahan pada pendekatan pembelajaran dan penilaian untuk merangsang pemikiran matematika pada siswa sehingga dapat membantu siswa untuk meningkatkan kemampuan berpikir kreatif. Salah satu pendekatan yang dapat digunakan adalah pendekatan ilmiah (Scientific Approach). Pendekatan ilmiah dalam pembelajaran meliputi lima pengalaman belajar pokok yaitu mengamati, menanya, mengumpulkan informasi/mencoba, mengasosiasi/ menalar, dan mengomunikasikan.

Pendekatan ilmiah dalam kurikulum 2013 lebih dikenal dengan pendekatan saintifik. Pembelajaran dengan menggunakan pendekatan saintifik tidak hanya memandang hasil belajar saja sebagai tujuan akhir. Namun, proses pembelajarannya juga dianggap sangat penting. Pembelajaran dengan pendekatan saintifik menerapkan keterampilan proses seperti mengamati, mengklasifikasi, mengukur, meramalkan, dan menyimpulkan. Dalam melaksanakan proses- 
proses tersebut, bantuan guru masih diperlukan. Akan tetapi bantuan guru tersebut harus semakin berkurang dengan semakin bertambah dewasanya siswa atau semakin tingginya kelas siswa. Siswa dituntut untuk lebih banyak mencari tahu dan bukan diberi tahu. Maksudnya adalah siswa dapat memperoleh informasi dari mana saja, kapan saja, dan tidak hanya tergantung pada informasi searah dari guru. Dalam penerapan pendekatan saintifik, peran guru adalah sebagai fasilitator. Pembelajaran seyogyanya sebanyak mungkin melibatkan siswa agar mereka mampu berpikir secara kreatif dalam menyelesaikan masalah matematika.

Berdasarkan uraian diatas menegaskan bahwa meningkatkan kemampuan berpikir siswa dalam pembelajaran matematika sangat penting dan perlu dikembangkan. Diharapkan melalui penerapan model pembelajaran dengan pendekatan Saintifik dapat meningkatkan kemampuan berpikir siswa dalam pembelajaran matematika.

\section{METODE}

Metode yang digunakan dalam penulisan artikel ini adalah library research (studi pustaka). Library research adalah kegiatan yang dilakukan peneliti untuk memperoleh segala informasi yang sesuai dengan topik dan masalah yang sedang dibahas. Perolehan informasi tersebut dapat dilakukan dengan menelaah buku, jurnal, artikel, dan laporan.

Penelitian oleh Surasmi (2014) yang berjudul "Penerapan Pendekatan Saintifik dalam Proses Pembelajaran Kurikulum 2013" mengungkapkan bahwa pembelajaran dengan pendekatan saintifik adalah proses pembelajaran yang dirancang sedemikian rupa agar peserta didik secara aktif mengonstruk konsep, hukum atau prinsip melalui tahapan-tahapan mengamati, merumuskan masalah, merumuskan hipotesis, mengumpulkan data, menganalisis data, menarik kesimpulan dan mengomunikasikan konsep, hukum, atau prinsip yang ditemukan sehingga siswa dapat mengembangkan karakter dan memperoleh hasil belajar yang tinggi.

Penelitian oleh Pratiwi (2018) yang berjudul "Optimalisasi Pendekatan Saintifik dengan Pembelajaran Inkuiri untuk Meningkatkan Kemampuan Berpikir Kritis di Madrasah Ibtidaiyah" menyimpulkan bahwa dalam implementasi pendekatan Saintifik dengan pembelajaran Inkuiri di Madrasah Ibtidaiyah dapat meningkatkan kemampuan berpikir kritis siswa.

\section{HASIL DAN PEMBAHASAN}

\section{Kemampuan Berpikir Siswa}

Menurut kamus bahasa Indonesia Poerwadarminta (dalam Soviawati, 2011) disebutkan bahwa berpikir adalah menggunakan akal budi untuk mempertimbangkan, memutuskan sesuatu. Berpikir merupakan sebuah proses untuk mempertimbangkan dan memutuskan segala sesuatu yang berkaitan dengan seorang individu. Kemampuan berpikir seseorang untuk mengerti dan memahami suatu hal dapat dibentuk dan dikembangkan tergantung dari kematangan intelektual serta yang diperolehnya dari belajar selama waktu tertentu. Pentingnya kemampuan berpikir pada pelaksanaan pembelajaran matematika, jika dihubungkan dengan teori Piaget (teori perkembangan kognitif). Maka berdasarkan teori ini, proses belajar dapat berlangsung apabila terjadi proses pengolahan data yang aktif dipihak pembelajar. Pengolahan data yang aktif adalah kegiatan lanjutan pembelajar dari kegiatan mencari informasi yang dilanjutkan dengan kegiatan penemuan (Departemen Pendidikan Nasional, 2007).

Menurut teori kognitif Bruner, belajar merupakan proses aktif di mana siswa mengkonstruk gagasan atau konsep baru berdasarkan pengetahuan yang telah dimiliki sebelumnya. Soekamto dan Winataputra (1996) menjelaskan bahwa menurut Bruner, perkembangan kognitif seseorang dapat ditingkatkan yaitu dengan memberi bahan sesuai dengan materi yang akan dipelajari dan menyajikannya sesuai dengan tingkat perkembangannya. Beberapa prinsip Bruner, yaitu:

a) Makin tinggi tingkat perkembangan intelektual, makin meningkat pula ketidaktergantungan individu terhadap stimulus yang diberikan;

b) Pertumbuhan seseorang tergantung pada perkembangan kemampuan internal untuk menyimpan dan memproses informasi. Data yang diterima orang dari luar perlu diolah secara mental;

c) Perkembangan intelektual meliputi peningkatan kemampuan untuk mengutarakan pendapat dan gagasan melalui simbol; 
d) Untuk mengembangkan kognitif seseorang diperlukan interaksi yang sistematik antara pengajar dan yang diajar;

e) Perkembangan kognitif meningkatkan kemampuan seseorang untuk memikirkan beberapa alterntif secara serentak, memberikan perhatian kepada beberapa stimuli dan situassi sekaligus, serta melakukan kegiatan-kegiatan.

Selanjutnya perkembangan kemampuan berpikir siswa dalam belajar dapat dilakukan dengan tiga tahapan berpikir yaitu: enaktif, ikonik dan simbolik. Adapun tahapan-tahapan tersebut dapat dilihat pada tabel berikut ini:

Tabel 1. Perkembangan Berpikir menurut Bruner

\begin{tabular}{|c|c|}
\hline $\begin{array}{c}\text { Tahap Perkembangan } \\
\text { Berpikir }\end{array}$ & Kemampuan-kemampuan Berpikir \\
\hline 1. Enaktif & $\begin{array}{l}\text { a. Pada masa anak-anak, apa yang dipelajari, dikenal ataupun } \\
\text { yang diketahui siswa hanya sebatas dalam ingatan. } \\
\text { b. Belum dapat memproses informasi yang akan terjadi. } \\
\text { c. Informasi masih terbatas pada ruang dan waktu. } \\
\text { d. Informasi yang diterima sebagaimana adanya. }\end{array}$ \\
\hline 2. Ikonik & $\begin{array}{l}\text { a. Dapat mencerna dan memahami informasi yang tidak ada di } \\
\text { lingkungan geografis disekitar mereka atau pada waktu } \\
\text { sekarang. } \\
\text { b. Dapat menggali informasi lebih jauh dari apa yang tertulis dan } \\
\text { diberikan. } \\
\text { c. Berpikir logis dan tingkat abstraksi konsep yang masih } \\
\text { rendah. }\end{array}$ \\
\hline
\end{tabular}

3. Simbolik

a. Berpikir abstrak cukup kuat untuk dijadikan dasar keilmuan.

b. Memahami simbol-simbol bahasa matematika atau disiplin ilmu lainnya sebagaimana harusnya.

c. Analisis, sintesis maupun evaluatif.

Peran utama pendidik pada akhirnya adalah memahami bagaimana cara berpikir siswa dengan potensi otak yang dimilikinya serta menghormati sistem pembelajaran individualnya. Hal ini dilakukan untuk membantu siswa berkembang menjadi diri mereka yang terbaik.

\section{Pendekatan Saintifik}

Pendekatan saintifik merupakan cara pandang baru dalam dunia pendidikan di Indonesia sebagai implementasi dari pelaksanaan Kurikulum 2013. Pendekatan saintifik adalah metode pendekatan dalam menemukan ilmu pengetahuan. Dalam pendekatan ini, siswa di dalam kelas berusaha untuk menemukan sendiri konsep materi yang dipelajari melalui konstruksi pengetahuan yang telah dimiliki sebelumnya (Wakhidah, et al., tanpa tahun). Dalam proses pembelajaran menggunakan pendekatan saintifik, siswa difasilitasi untuk menjadi aktif membangun konsep melalui tahapan-tahapan saintifik yaitu mengamati, menanya, mengumpulkan informasi, mengasosiasikan, dan mengkomunikasikan.

Secara lebih rinci, Kemendikbud (2014) menjelaskan tahapan-tahapan pembelajaran pendekatan saintifik sebagai berikut:

1. Mengamati 
Mengamati/observasi pada dasarnya adalah kegiatan memperhatikan sesuatu dengan menggunakan indera secara cermat. Menurut Permendikbud Nomor 81A Tahun 2013, kegiatan mengamati dilakukan melalui kegiatan melihat, menyimak, mendengar, dan membaca. Kompetensi yang diharapkan adalah melatih kesungguhan, ketelitian, dan mencari informasi. Metode mengamati adalah salah satu strategi pembelajaran yang menggunakan pendekatan kontekstual dan media asli agar kegiatan belajar menjadi bermakna. Dalam kegiatan ini, siswa akan memperoleh hubungan antara apa yang diamati dengan materi yang akan dipelajari.

2. Menanya

Menanya adalah kegiatan dimana siswa mengajukan pertanyaan tentang hal-hal yang tidak diketahui atau pertanyaan untuk mendapatkan pengetahuan tambahan. Pertanyaan biasanya muncul karena terdapat ketidakcocokan antara apa yang diamati dengan apa yang dipikirkan oleh siswa. Menurut Permendikbud Nomor 81A Tahun 2013, kompetensi yang diharapkan adalah mengembangkan kreativitas, rasa ingin tahu, kemampuan merumuskan pertanyaan, dan membentuk pikiran kritis. Dalam kegiatan ini, akan menciptakan rasa keingintahuan siswa.

3. Mengumpulkan informasi

Mengumpulkan informasi adalah kegiatan dimana siswa mampu menemukan sumber informasi, memilih informasi yang diperlukan, mengolah dan menganalisisnya, dan mengambil kesimpulan. Permendikbud Nomor 81A Tahun 2013 menjelaskan bahwa mengumpulkan informasi dapat dilakukan dengan eksperimen, membaca sumber lain selain buku teks, dan wawancara dengan narasumber.

4. Mengasosiasikan

Mengasosiasi adalah kegiatan mengaitkan antara satu fakta dengan fakta yang lain, terutama hasil dari mengumpulkan informasi. Hasil dari kegiatan ini adalah siswa akan menghasilkan kesimpulan. Dalam kegiatan ini, siswa dituntut meningkatkan kemampuan berpikirnya untuk menyelesaikan suatu masalah.

5. Mengkomunikasikan

Teori Vygotski menekankan bahwa kemampuan kognitif manusia berasal dari interaksi sosial masing-masing individu dalam konteks budaya sehingga pembelajaran terjadi saat pebelajar bekerja atau menangani tugas yang sedang dipelajarinya (Wakhidah, et al., tanpa tahun). Interaksi sosial dapat dilakukan melalui kegiatan mengkomunikasikan. Mengkomunikasikan adalah kegiatan menyampaikan hasil temuan dan kesimpulannya. Mengkomunikasikan dapat dilakukan secara lisan, tertulis, atau dengan media lainnya.

Menurut Kosasih (dalam Sandy et al, 2016) karakteristik pendekatan saintifik adalah (1) materi pembelajaran dipahami dengan standar logika yang sesuai dengan taraf kedewasaan siswa, tetapi memungkinkan bagi siswa untuk mengkritisi, dan mengetahui prosedur pemerolehannya, serta kelemahan-kelemahannya, (2) interaksi pembelajaran berlangsung secara terbuka dan objektif. Siswa memiliki kesempatan untuk mengemukakan pemikiran, perasaan, sikap dan pengalamannya. Namun, siswa tetap memerhatikan sikap ilmiah dan tanggung jawab, dan (3) siswa didorong untuk berpikir analistis dan kritis, tepat dalam memahami, mengidentifikasi, memecahkan masalah, serta mengaplikasikan materi-materi pembelajaran.

\section{Peningkatan Kemampuan Berpikir Siswa dalam Pembelajaran Matematika dengan Pendekatan Saintifik}

Kemampuan berpikir siswa dalam matematika sangat perlu untuk dikembangkan. Dengan meningkatkan kemampuan berpikir siswa, maka prestasi akademik siswa tersebut akan meningkat. Untuk meningkatkan kemampuan berpikir tersebut, guru harus berupaya untuk menciptakan perubahan dalam pendekatan dan pengajaran dalam matematika yang cocok. Model atau pendekatan ini haruslah sesuai dengan materi yang akan diajarkan serta dapat mengoptimalkan suasana belajar. Salah satu pendekatan yang dapat diterapkan adalah pendekatan saintifik. Telah dijelaskan bahwa pendekatan saintifik pada kurikulum 2013 merupakan suatu proses pembelajaran yang dirancang sedemikian rupa agar peserta didik secara 
aktif mengkonstruk konsep, hukum atau prinsip melalui tahapan mengamati, menanya, mengumpulkan informasi, mengasosiasikan, dan mengkomunikasikan. Keunggulan pendekatan saintifik diantaranya meningkatkan kemampuan berpikir siswa, dapat membentuk kemampuan siswa dalam menyelesaikan masalah secara sistematik, terciptanya kondisi pembelajaran dimana siswa merasa belajar itu merupakan kebutuhan, diperoleh hasil belajar yang tinggi, melatih siswa dalam mengkomunikasikan ide-ide, dan untuk mengembangkan karakter siswa (Ine, 2015). Menurut Pratiwi (2018), tujuan pembelajaran dengan pendekatan saintifik salah satunya yaitu meningkatkan kemampuan intelektual, khususnya kemampuan berpikir tingkat tinggi peserta didik. Prinsip pembelajaran dengan pendekatan saintifik antara lain mendorong terjadinya peningkatan kecakapan berpikir siswa dan melibatkan proses kognitif yang potensial dalam merangsang perkembangan intelektual, khususnya keterampilan berpikir tingkat tinggi siswa.

Salah satu komponen penting dalam mengajar menggunakan pendekatan saintifik adalah menyajikan pembelajaran yang dapat meningkatkan rasa keingintahuan dari siswa (Foster a sense of wonder). Dalam hal ini, guru dapat memancing keingintahuan siswa dengan memberi pertanyaan-pertanyaan tentang matematika yang dapat meningkatkan keterampilan berpikir siswa dengan menggunakan dan mengembangkan kata tanya yang dikemukakan oleh Way (2018) antara lain: What is the same? (Apa yang sama?), What is different? (Apa perbedaanya?), What do you think...? (Apa yang kamu pikirkan...?), What would happen if....? (Apa yang terjadi jika...?). Guru dapat mengkombinasikan dengan kata kerja operasional yang dapat membuat siswa lebih aktif dan kreatif dalam berpikir.

Pemberian pertanyaan oleh guru juga harus memperhatikan kualitas pertanyaan yang diberikan. Menurut Pratiwi (2018), tahapan-tahapan pemberian pertanyaan oleh guru untuk meningkatkan kualitas pertanyaan antara lain:

1. Berikan pertanyaan secara berjenjang.

Pertanyaan secara berjenjang adalah pertanyaan yang diberikan dari tahap mudah ke tahap sulit. Pemberian pertanyaan berjenjang dapat meningkatkan mental berpikir siswa. Guru harus menghindari pemberian pertanyaan bolak-balik karena hal tersebut dapat mengakibatkan siswa bingung dalam berpikir.

2. Gunakan pertanyaan-pertanyaan untuk melacak.

Pertanyaan-pertanyaan yang bersifatnya melacak perlu diterapkan dalam suatu pembelajaran. Hal ini dikarenakan pertanyaan melacak dapat meningkatkan kualitas bertanya sebagai alat pembelajaran.

Guru juga dapat memberikan soal pertanyaan yang menarik serta menantang agar rasa ingin tahu siswa selalu muncul dan ide-ide kreatif mereka terasah dengan baik. Memberikan pertanyaan-pertanyaan menarik dan menantang merupakan salah satu hal yang dilakukan guru dalam kelas. Hal ini sejalan dengan pendapat Protheroe (Anonim, tanpa tahun) yaitu hal yang harus dilakukan guru matematika di kelas antara lain:

1. Mendemonstrasikan penerimaan ide-ide yang berbeda dari siswa.

Guru menantang siswa untuk berpikir secara mendalam tentang masalah yang mereka selesaikan. Siswa juga menjelaskan bagaimana mereka menemukan solusi dan mengapa mereka memilih solusi tersebut.

2. Mempengaruhi pembelajaran dengan mengajukan pertanyaan yang menantang dan menarik.

Guru mengajukan pertanyaan yang tidak hanya merangsang keingintahuan siswa, namun juga mendorong mereka untuk menyelidiki lebih lanjut.

3. Membangun sikap positif tentang matematika dan tentang kemampuan siswa untuk "melakukan" matematika.

Guru membangun rasa keyakinan pada siswa bahwa tidak hanya tujuan "mengerjakan matematika" dapat dicapai, namun mereka secara pribadi juga mampu mencapai tujuan tersebut. 


\section{SIMPULAN DAN SARAN}

Kemampuan berpikir siswa dalam pembelajaran matematika perlu ditingkatkan. Untuk meningkatkan kemampuan berpikir siswa dapat dilakukan pendekatan saintifik. Pendekatan saintifik merupakan implementasi dari pelaksanaan kurikulum 2013. Tahapan-tahapan saintifik yaitu mengamati, menanya, mengumpulkan informasi, mengasosiasikan, dan mengkomunikasikan. Pembelajaran dengan pendekatan saintifik mempunyai tujuan salah satunya yaitu meningkatkan kemampuan intelektual, khususnya kemampuan berpikir tingkat tinggi siswa. Pembelajaran dengan pendekatan saintifik juga memiliki prinsip antara lain mendorong terjadinya peningkatan kecakapan berpikir siswa dan melibatkan proses kognitif yang potensial dalam merangsang perkembangan intelektual, khususnya keterampilan berpikir tingkat tinggi siswa. Melalui pendekatan saintifik, guru dapat mengembangkan rasa keingintahuan siswa yaitu dengan memberikan siswa pertanyaan-pertanyaan menarik dan menantang yang membuat siswa berpikir secara aktif dan kreatif. Sehingga dengan demikian, pendekatan saintifik dapat meningkatkan kemampuan berpikir siswa dalam pembelajaran matematika.

Saran dalam penelitian ini adalah: (1) Pembelajaran matematika dengan pendekatan saintifik dapat dijadikan sebagai salah satu pendekatan pembelajaran di kelas untuk meningkatkan kemampuan berpikir siswa; (2) Perlunya mengembangkan pertanyaan-pertanyaan yang dapat meningkatkan kemampuan berpikir siswa; (3) Perlunya mengembangkan pertanyaan-pertanyaan menantang atau berkaitan dengan masalah kontekstual bagi siswa.

\section{DAFTAR RUJUKAN}

Anonim. Tanpa Tahun. Algebra Readiness the Effective Mathematics Classroom. Tersedia: https://vhsteams.files.wordpress.com/2013/04/algebrasupport.pdf yang diunduh pada 22 Oktober 2019.

Amir, Z. 2015. Mengungkap Seni Bermatematika dalam Pembelajaran. Suska Journal of Mathematics Education Volume 1 yang diunduh pada 22 Oktober 2019.

Conklin, W. \& J. Manfro. 2012. Higher order thinking skills to develop 21st century learners. Shell Education Publishing, Inc. Huntington.

Departemen Pendidikan Nasional. 2007. Naskah Akademik Kajian Kebijakan Kurikulum Mata Pelajaran Ilmu Pengetahuan Sosial (IPS). Jakarta: Depdiknas. Tersedia: http://www.academia.edu/download/31846047/52_Kajian_Kebijakan_Kurikulum_IPS.pdf

Hidayati, A. U. 2017. Melatih Keterampilan Berpikir Tingkat Tinggi dalam Pembelajaran Matematika pada Siswa Sekolah Dasar. Jurnal Pendidikan dan Pembelajaran Dasar Volume 4 yang diunduh pada 30 Oktober 2019.

Ine, M. E. 2015. Penerapan Pendekatan Scientific untuk Meningkatkan Prestasi Belajar Siswa pada Mata Pelajaran Ekonomi Pokok Bahasan Pasar. Prosiding Seminar Nasional yang diunduh pada 21 Desember 2019.

Kemendikbud. 2014. Konsep dan Implementasi Kurikulum 2013. Jakarta: Kemendikbud. Tersedia: https://www.kemdikbud.go.id/kemdikbud/dokumen/Paparan/Paparan\%20Wamendik.pdf

Lambertus. 2009. Pentingnya Melatih Keterampilan Berpikir Kritis dalam Pembelajaran Matematika SD. Forum Kependidikan Volume 28 yang diunduh pada 22 Desember 2019.

Permendikbud Nomor 81A Tahun 2013 Tentang Implementasi Kurikulum. Jakarta: Depdikbud.

Pratiwi, W. 2018. Optimalisasi Pendekatan Saintifik dengan Pembelajaran Inkuiri untuk Meningkatkan Kemampuan Berpikir Kritis di Madrasah Ibtidaiyah. Insania, Vol. 23, No. 2 yang diunduh pada 10 Agustus 2020.

Sandy, I. P. A. W., I. W. Sujana, \& I. W. Darsana. 2016. Penerapan PBL dalam Pendekatan Saintifik untuk Meningkatkan Kemampuan Berpikir Kritis dan Penguasaan Kompetensi Pengetahuan IPS. e-Journal PGSD Universitas Pendidikan Ganesha yang diunduh pada 8 Agustus 2020.

Soekamto, T. \& U. S. Winataputra. 1996. Teori Belajar dan Model-Model Pembelajaran. Jakarta: Dirjen Dikti Pendidikan dan Kebudayaan. 
Soviawati, E. 2011. "Pendekatan Matematika Realistik (PMR) untuk Meningkatkan Kemampuan Berpikir Siswa di Tingkat Sekolah Dasar". Tersedia: http://jurnal.upi.edu/md/view/670/pendekatan-matematika-realistik-(pmr)-untukmeningkatkan-kemampuan-berfikir-siswa-di-tingkat-sekolah-dasar.html yang diunduh pada 30 Oktober 2019.

Sulistiani, E. \& Masrukan. 2016. "Pentingnya Berpikir Kritis dalam Pembelajaran Matematika untuk Menghadapi Tantangan MEA". Tersedia: https://journal.unnes.ac.id/sju/index.php/prisma/article/view/21554

Surasmi, W. A. 2014. "Penerapan Pendekatan Saintifik dalam Proses Pembelajaran Kurikulum 2013".

Tersedia: http://repository.ut.ac.id/1488/1/Artikel\%20Wuwuh\%20Asrining.pdf yang diunduh pada 30 Oktober 2019.

Utari, R. S., T. Saleh, \& Indaryanti. Tanpa Tahun. "Pelaksanaan Pembelajaran Matematika dengan Model Project Based Learning (PBL) di Kelas X SMA Negeri 1 Indralaya". Tersedia: $\quad$ https://www.slideshare.net/AmaBustam/jurnal-matematika-pelaksanaanpembelajran-matematika-dengan-project-baseed-learning

Wakhidah, N., M. Ibrahim, \& R. Agustini. Tanpa Tahun. Scaffolding Pendekatan Saintifik Strategi Untuk Menerapkan Pendekatan Saintifik dengan Mudah. Surabaya: Jaudar Press. Tersedia: http://digilib.uinsby.ac.id/15748/

Way, J. 2008. Using Questioning to Stimulate Mathematical Thinking. University of Sydney.

Widiani, T., M. Rif'at, \& R. Ijuddin. Tanpa Tahun. Penerapan Pendekatan Saintifik dan Pengaruhnya terhadap Kemampuan Komunikasi Matematis dan Berpikir Kreatif Siswa. Tersedia: http://jurnal.untan.ac.id/index.php/jpdpb/article/view/13550 yang diunduh pada 8 Agustus 2020. 